\section{A Cytosolic Heat Shock Protein Expressed in Carrot (Daucus carota L.) Enhances Cell Viability under Oxidative and Osmotic Stress Conditions}

\author{
Yeh-Jin Ahn ${ }^{1}$ and Na-Hyun Song \\ Department of Green Life Science, College of Convergence, Sangmyung \\ University, 7 Hongji-dong, Jongno-gu, Seoul 110-743, Korea
}

Additional index words. Daucus carota, gene expression, heat shock protein, molecular chaperone, osmotic stress, oxidative stress

\begin{abstract}
The expression and function of DcHsp17.7, a small heat shock protein expressed in carrot (Daucus carota L.), was examined under oxidative and osmotic stress conditions. Comparative analysis revealed that DcHsp17.7 is a cytosolic Class I protein. Sequence alignment showed that DcHsp17.7 has the characteristic $\alpha$-crystalline domaincontaining consensus regions I and II. Under oxidative [hydrogen peroxide $\left(\mathrm{H}_{2} \mathrm{O}_{2}\right)$ ] and osmotic (polyethylene glycol) stress conditions, DcHsp17.7 accumulated in carrot leaf tissue. To examine its function under these abiotic stress conditions, the coding sequence of DcHsp17.7 was introduced into Escherichia coli and expressed by isopropyl $\beta$-D-1thiogalactopyranoside treatment. Under both oxidative and osmotic stress conditions, heterologously expressed DcHsp17.7 enhanced bacterial cell viability. The expression level of soluble proteins was higher in transgenic cells expressing DcHsp17.7 when compared with controls under these stress conditions. These results suggest that DcHsp17.7 confers tolerance to both oxidative and osmotic stresses and thereby functions as a molecular chaperone during the stresses examined.
\end{abstract}

All living organisms synthesize a group of proteins called heat shock proteins (HSPs) when exposed to elevated temperatures or other abiotic stresses such as cold, salinity, drought, oxidation, and heavy metals (Vierling, 1991). These proteins are classified into five conserved classes based on their molecular weights: HSP100, HSP90, HSP70, HSP60, and small (s) HSPs (12 to $42 \mathrm{kDa}$; Waters et al., 1996). The sHSPs are more abundant and diverse in plants compared with other organisms (Sun et al., 2002). Haslbeck et al. (2005) have reported that the number of genes encoding sHSPs is one or two in bacteria and archaea, four in Drosophila melanogaster, 16 in Caenorhabditis elegans, 10 in Homo sapiens, and 19 in Arabidopsis thaliana. They are divided into seven subclasses based on their cellular localization and sequence homology. Three classes (Class I, II, and III) are localized in the cytosol/nucleus, whereas the other four classes are present in the peroxisome $(\mathrm{P})$, the endoplasmic reticulum (ER), the mitochondria (M), and the chloroplast (C). Such sHSPs

\footnotetext{
Received for publication 25 July 2011. Accepted for publication 19 Nov. 2011

This work was supported by the Basic Science Research Program through the National Research Foundation of Korea (NRF) funded by the Ministry of Education, Science and Technology (2010-0005142). We thank Ms. Jisun Kim for technical support.

${ }^{1}$ To whom reprint requests should be addressed; e-mail yjahn@smu.ac.kr.
}

are characterized by a conserved $\alpha$-crystalline domain (90 a.a.), which is also present in the $\alpha$-crystalline proteins of the vertebrate eye lens, located at their carboxyl-terminal. The $\alpha$-crystalline domain is further divided into consensus I and II regions separated by hydrophobic regions of various lengths (Sun et al., 2002). In contrast, the amino-terminals of sHSPs vary greatly among the different classes. The $\alpha$-crystalline domain is known to exert molecular chaperone activity, thereby preventing protein denaturation and/or correcting the folding of partially unfolded proteins under stress conditions.

Our recent studies have shown that sHSPs are expressed not only under heat stress, but also under various abiotic stresses, where DcHsp17.7 in carrot (Daucus carota L.) was expressed under conditions of heat (Kim and Ahn, 2009), cold (Song and Ahn, 2010), and salinity (Song and Ahn, 2011). Furthermore, the heterologous expression of DcHsp17.7 enhanced cell viability in transgenic $E$. coli under these environmental stress conditions, suggesting that DcHsp17.7 may confer multiple stress tolerances. If so, DcHsp17.7 would be a valuable candidate for the development of transgenic plants possessing multiple stress tolerance.

We examined here the expression and function of DcHsp17.7 under oxidative and osmotic stress conditions, which are abiotic stresses that frequently accompany heat stress (Vandenbroucke et al., 2008). In plants, oxidative stress results in the accumulation of reactive oxygen species (ROS; Desikan et al., 2001). Increased ROS such as $\mathrm{H}_{2} \mathrm{O}_{2}$ causes an imbalance in cellular redox state, thereby damaging the proteins, lipids, and nucleic acids of living cells (Vandenbroucke et al., 2008). Drought and desertification (i.e., osmotic stress) result from global warming and attendant climate changes (Ashraf, 1994). According to a report by Johnson et al. (2006), 44\% of arable lands are affected by desertification.

To examine whether DcHsp17.7 is involved in conferring tolerance to oxidative and osmotic stresses, we studied the accumulation of DcHsp17.7 in stressed tissues using a polyclonal antibody raised against DcHsp17.7. Then, the DcHsp17.7 gene was introduced into $E$. coli to analyze its action under these abiotic stress conditions. In this case, the cell viability and protein solubility of transgenic $E$. coli expressing DcHsp17.7 were examined under stress conditions to determine whether the protein confers tolerance to oxidative and/or osmotic stresses.

\section{Materials and Methods}

Comparative analysis of DcHsp17.7 with various plant small heat shock proteins. A dendrogram was constructed with the neighborjoining method (Saitou and Nei, 1987) based on the Kimura 2-parameter distance model using MEGA4 software (Tamura et al., 2007; Fig. 1). The percentages of replicate trees in which the associated taxa clustered together in the bootstrap analysis (1000 replicates) are shown next to the branches. The representative genes studied or cited in recent plant heat stress studies were chosen for this analysis. The accessions for the DNA sequences analyzed in this study were obtained from Genbank.

Sequence alignment of DcHsp17.7 with other cytosolic Class I small heat shock proteins. The amino sequences of DcHsp17.7 and other representative cytosolic Class I sHSPs were aligned using ClustalW software (Higgins and Sharp, 1988). The sequences are derived from DcHsp17.7 (Daucus carota; X53851), PsHsp18.1 (Pisum sativum; M33899), MsHsp18.2 (Medicago sativa; X58711), MtHsp20 (Medicago truncatula; AC149642), NtHsp17.8 (Nicotiana tabacum; HQ014606), GmHsp17.6 (Glycine max; M11317), CpHsp17.5 (Carica papaya; AY387588), LeHsp17.8 (Lycopersicon esculentum; AF123256), and LpHsp19.9 (Lycopersicon peruvianum; AJ225047). The consensus regions (I and II) of the $\alpha$-crystallin domain were indicated in Figure 2. The secondary structure in the $\alpha$-crystallin domain was assigned based on the study by Van Montfort et al. (2001) and was indicated above the alignment.

Accumulation of DcHsp17.7 under oxidative and osmotic stresses. Carrot plants (Daucus carota L. cv. Mussangochon) were grown in a controlled environmental chamber $\left(18-21{ }^{\circ} \mathrm{C}\right.$, 10-14 h, night-day) with light supplemented by fluorescent lamp at an intensity of 200 


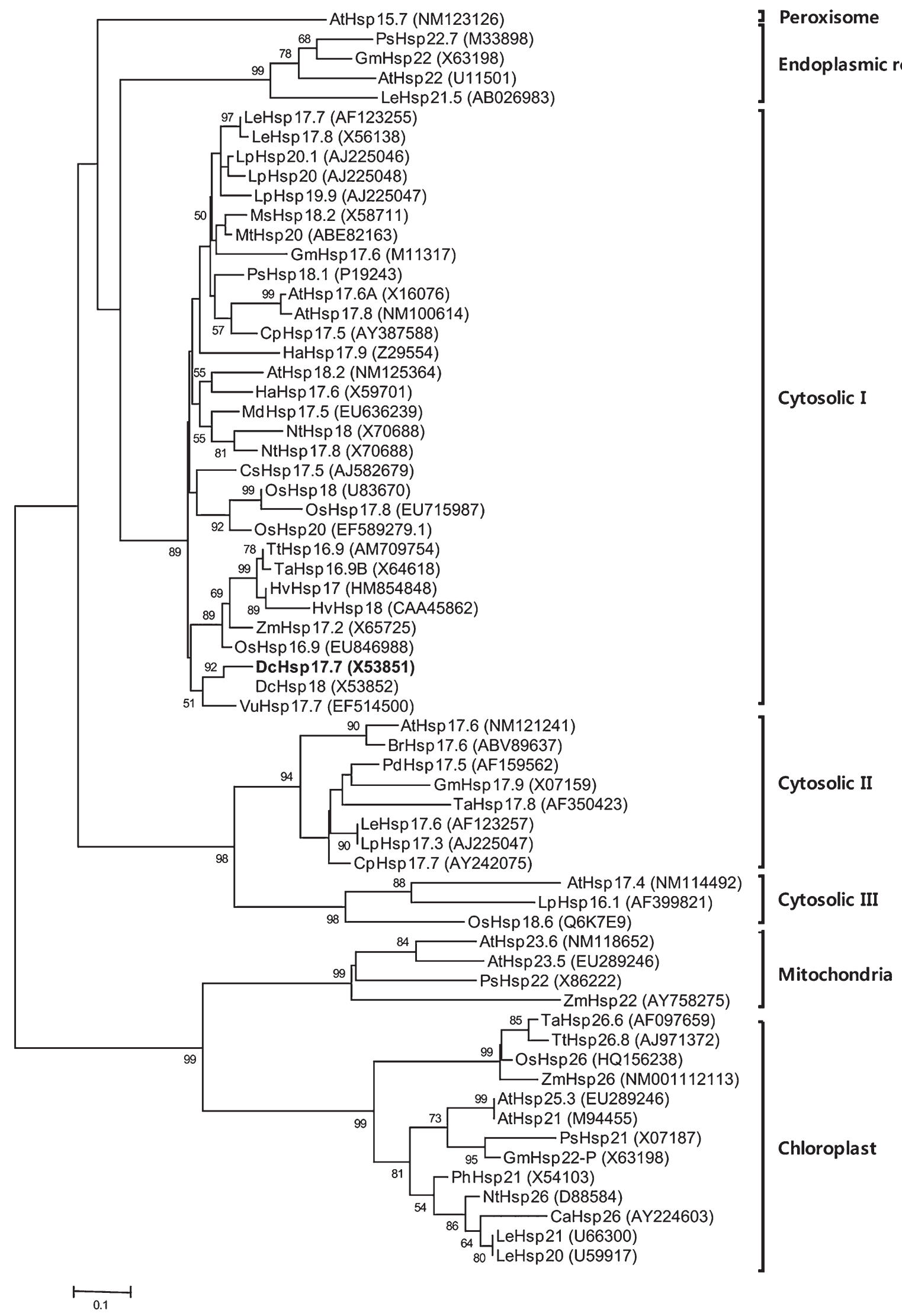

Fig. 1. Comparative analysis of DcHsp17.7 of various plant small heat shock proteins (sHSPs). A dendrogram was constructed with the neighbor-joining method (Kimura 2-parameter distance model) using MEGA4 software. The bootstrap values from 1000 replications are indicated next to the branches. The accession numbers for the genes analyzed in this study were obtained from Genbank and indicated in blanks. The abbreviations of species are: At = Arabidopsis thaliana; $\mathrm{Br}=$ Brassica rapa $; \mathrm{Ca}=$ Capsicum annum $; \mathrm{Cp}=$ Carica papaya $; \mathrm{Cs}=$ Castanea sativa $; \mathrm{Gm}=$ Glycine max $; \mathrm{Ha}=$ Helianthus annuus $; \mathrm{Hv}=$ Hordeum vulgare; $\mathrm{Le}=$ Lycopersicon esculentum $; \mathrm{Lp}=$ Lycopersicon peruvianum; $\mathrm{Md}=$ Malus domestica $; \mathrm{Ms}=$ Medicago sativa $; \mathrm{Mt}=$ Medicago truncatula $; \mathrm{Nt}=$ Nicotiana tabacum $; \mathrm{Os}=$ Oryza sativa $; \mathrm{Pd}=$ Prunus dulcis $; \mathrm{Ph}=$ Petunia hybrida $; \mathrm{Ps}=$ Pisum sativum $; \mathrm{Ta}=$ Triticum aestivum $; \mathrm{Tt}=$ Triticum turgidum $; \mathrm{Vu}=$ Vigna unguiculata; and $\mathrm{Zm}=$ Zea mays. DcHsp17.7 is marked in bold. 
$\mu \mathrm{E} \cdot \mathrm{m}^{-2} \cdot \mathrm{s}^{-1}$ and $60 \%$ relative humidity. Two- to 3-month-old plants were used throughout the experiment. For oxidative and osmotic stress treatments, leaf tissue was placed in either $\mathrm{H}_{2} \mathrm{O}_{2}$ or polyethylene glycol (PEG) $(5 \% ; 1,3$, or $5 \mathrm{~h}$ ). Proteins were extracted as previously described (Ahn et al., 2004) using an extraction buffer $[0.3 \%$ sodium dodecyl sulfate (SDS), $200 \mathrm{~mm}$ dithiothreitol, $28 \mathrm{~mm}$ Tris$\mathrm{HCl}$, and $22 \mathrm{~mm}$ Tris-base]. Protein concentrations were then quantified using the Bradford assay (Bradford, 1976). Equal amounts of protein $(30 \mu \mathrm{g})$ were resolved on a $17 \%$ SDS polyacrylamide electrophoresis gel and electroblotted to a polyvinylidene difluoride membrane (Bio-Rad, Hercules, CA). An immunoblot analysis was performed using a polyclonal antibody raised against DcHsp17.7 and an ECL Plus system according to the manufacturer's instructions (Amersham Biosciences, Pittsburgh, PA). To quantify the expression level of DcHsp17.7, chemiluminescent signals were measured using IMAGER and 1D MAIN (Bioneer, Seoul, Korea). The values were normalized to the expression level at $1 \mathrm{~h}$ in leaf tissue.

Heterologous expression of DcHsp17.7 in Escherichia coli. The coding region of the DcHsp17.7 gene (NCBI accession number $\mathrm{X} 53851)$ was introduced into $E$. coli using a pET11a expression vector described previously by Kim and Ahn (2009). Transformed E. coli cells containing the pET11a-DcHsp17.7 recombinant vector and control cells containing the unmodified pET11a expression vector were cultured overnight in Luria-Bertani broth (LB; BD Difco, Sparks, MD) containing 100 $\mu \mathrm{g} \cdot \mathrm{mL}^{-1}$ ampicillin with shaking at $37^{\circ} \mathrm{C}$. Overnight cultures were diluted 1:1000 with fresh LB broth containing ampicillin and then continuously incubated at $37^{\circ} \mathrm{C}$. When cell cultures were grown to an O.D. 600 of 0.6 , isopropyl b-D-thiogalactopyranoside (IPTG) was added to a final concentration of $1 \mathrm{~mm}$ to induce the expression of the DcHsp17.7 gene, and bacterial cells were then cultured for an additional $2 \mathrm{~h}$. For oxidative and osmotic stress treatments, bacterial cell lines were subjected to $\mathrm{H}_{2} \mathrm{O}_{2}$ (up to $0.3 \mathrm{~mm}$ for $3 \mathrm{~h}$ ) and PEG (20\% up to $8 \mathrm{~h}$ ), respectively. Bacterial proteins were extracted using ultrasonification and resolved on a $17 \%$ SDS PAGE gel. To confirm the heterologous expression of DcHsp17.7 in $E$. coli, immunoblot analyses were performed using a polyclonal antibody raised against DcHsp17.7 as described previously. To quantify the expression level of DcHsp17.7, chemiluminescent signals were measured using IMAGER and 1D MAIN (Bioneer). The values were normalized to the IPTG-induced control level before stress treatment.

Enhancement of cell viability by DcHsp17.7 under oxidative and osmotic stresses. Overnight cell culture and IPTG treatment were performed as described previously. Transgenic E. coli expressing DcHsp17.7 and control cells were subjected to $\mathrm{H}_{2} \mathrm{O}_{2}$ (up to $0.3 \mathrm{~mm}$ for $3 \mathrm{~h}$ ) or PEG ( $20 \%$ up to $8 \mathrm{~h}$ ). Bacterial cells were then plated on LB medium containing ampicillin and incubated at $37^{\circ} \mathrm{C}$. After overnight incubation, the number of surviving colonies was counted and the percentages of survival were calculated.

The molecular chaperone function of DcHsp17.7 under oxidative and osmotic stress conditions. Overnight bacterial cell culture and IPTG treatment were performed as described previously. Bacterial proteins were extracted using SMART Bacterial Protein Extraction Solution (Intron, Seoul, Korea). Equal amounts of protein $(900 \mu \mathrm{g})$ were added to $500 \mu \mathrm{L}$ of protein extraction buffer containing either $\mathrm{H}_{2} \mathrm{O}_{2}$ (up to $5 \mathrm{M}$ ) or PEG (up to $20 \%$ ) and incubated at $25^{\circ} \mathrm{C}$ for $2 \mathrm{~h}$ followed by a centrifugation step at $20,900 \mathrm{~g}$ for $1 \mathrm{~h}$. The amount of soluble protein was quantified by measuring O.D.600.

\section{Results and Discussion}

Comparative analysis of DcHsp17.7 of various plant small heat shock proteins. Plant sHSPs are divided into seven subfamilies depending on their cellular localization and sequence homology, including three cytosolic (CI, CII, and CIII) groups, one peroxisome group, one endoplasmic reticulum group, one mitochondrial group, and one chloroplastic group (Fig. 1). Based on this analysis, DcHsp17.7 was assigned to the largest cytosolic Class I subfamily. This is consistent with our previous result, which showed that DcHsp17.7 fused with green fluorescent protein was localized to the cytosol and nucleus (Ahn and Zimmerman, 2007). In addition to the three cytosolic groups presented in Figure 1, recent studies have reported that there could be additional cytosolic groups of plant sHSPs such as seven and nine nucleocytoplasmic classes in Arabidopsis (Siddique et al., 2008) and rice (Sarkar et al., 2009), respectively. The possible functional differences among the various cytosolic subfamilies could be studied by, for example, examining their expression patterns under various stress conditions.

Sequence alignment of DcHsp17.7 with other cytosolic Class I small heat shock proteins. Sequence alignment analysis showed that DcHsp17.7 has the structural characteristics of the cytosolic Class I sHSPs (Fig. 2). The protein contains an $\alpha$-crystalline domain containing consensus regions I and II at its $\mathrm{C}$-terminal. In contrast, the $\mathrm{N}$-terminal region was rather divergent in amino acid sequence and size. Among the members of a plant sHSP subfamily, the sequence homology can be up to $90 \%$ (Lindquist and Craig, 1988). This high-sequence homology is mainly the result of their much-conserved $\mathrm{C}$-terminal domain. Studies have shown that both $\mathrm{C}$ - and N-terminal domains of sHSPs are involved in molecular chaperone activity and substrate specificity (Basha et al., 2006; Haslbeck et al., 2004). They reported that interaction between sHSPs and substrates is dynamic, involving a number of regions on the sHSPs. The function of the N- and Cterminal domains of DcHsp17.7 in substrate interaction and molecular chaperone function is being studied with truncated DcHsp17.7 constructs containing either of the domains.

Accumulation of DcHsp17.7 under oxidative and osmotic stress conditions. We have reported that DcHsp17.7 is expressed under

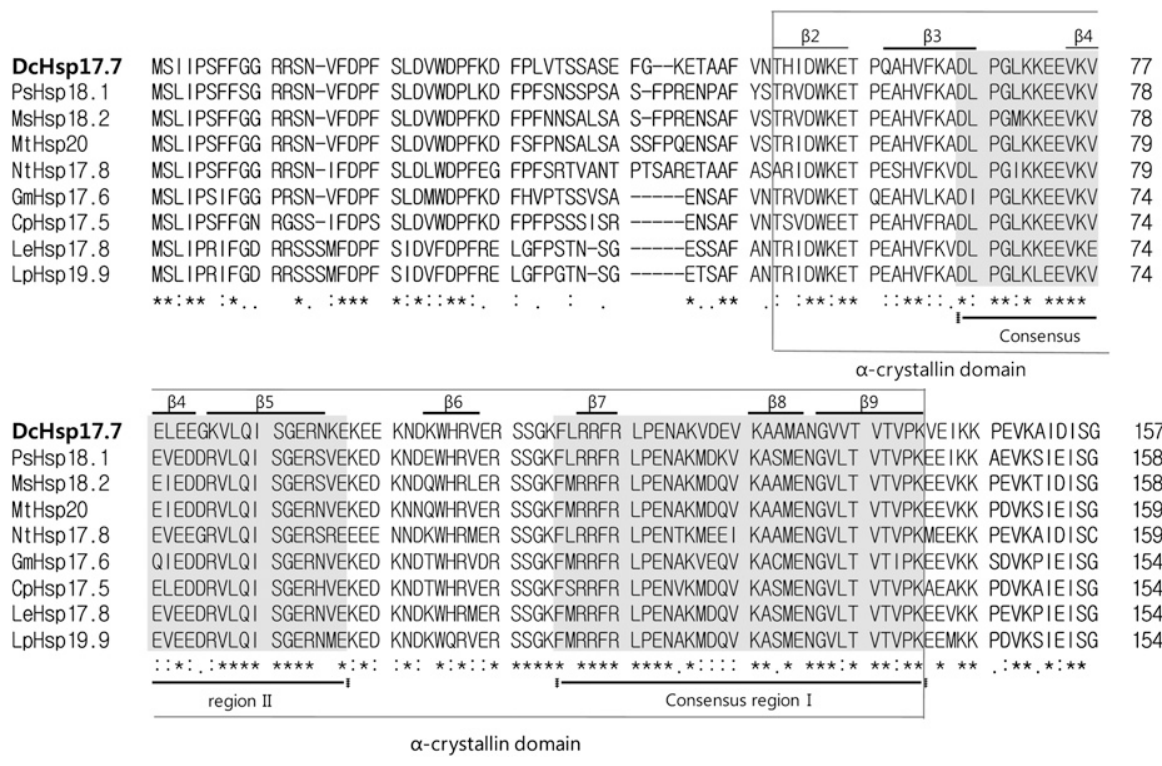

Fig. 2. Amino acid sequence alignment of DcHsp17.7 with various plant cytosolic class I small heat shock proteins (sHSPs). The amino sequences were aligned using the ClustalW software. The sequences are derived from DcHsp17.7 (Daucus carota; X53851), PsHsp18.1 (Pisum sativum; M33899), MsHsp18.2 (Medicago sativa; X58711), MtHsp20 (Medicago truncatula; AC149642), NtHsp17.8 (Nicotiana tabacum; HQ014606), GmHsp17.6 (Glycine max; M11317), CpHsp17.5 (Carica papaya; AY387588), LeHsp17.8 (Lycopersicon esculentum; AF123256), and LpHsp19.9 (Lycopersicon peruvianum; AJ225047). The conserved $\alpha$-crystallin domain, containing consensus regions I and II, is indicated. The secondary structure in the $\alpha$-crystallin domain is indicated above the alignment. Consensus line: identical residues in all sequences (*), conserved substitutions (:), semiconserved substitutions (.), and gaps introduced to optimize alignment (-). 
heat (Kim and Ahn, 2009), cold (Song and Ahn, 2010), and salinity (Song and Ahn, 2011) stress conditions. The present study showed that oxidative and osmotic stresses also induced the accumulation of DcHsp17.7, because the protein was detected in $\mathrm{H}_{2} \mathrm{O}_{2}$ treated (Fig. 3A) and PEG-treated (Fig. 3B) carrot leaf tissues. In the absence of stress, DcHsp17.7 was absent or present at a very low level. However, on exposure to oxidative stress, the level of DcHsp17.7 was increased up to $5 \mathrm{~h}$. Under osmotic stress, the level of DcHsp17.7 reached maximum at $3 \mathrm{~h}$ and then decreased up to $5 \mathrm{~h}$.

Previous studies have reported the accumulation of some plant sHSPs under oxidative (OsHsp26, Oryza sativa L., Lee et al., 2000; QsHsp10.4, Quercus suber L., Jofré et al., 2003; and Hsp21, Lycopersicon esculentum L., Neta-Sharir et al., 2005) and osmotic (GaHsp26, Gossypium arboretum L., Maqbool et al., 2010; At-Hsp17.6A, Arabidopsis thaliana L., Sun et al., 2001; and RcHsp17.8, Rosa chinensis L., Jiang et al., 2009) stress conditions. Taken together, plant sHSPs can be expressed not only under heat conditions, but also under various abiotic stresses such as oxidative and osmotic stress conditions. These findings suggest that plant sHSPs play a possible role in the enhancement
A
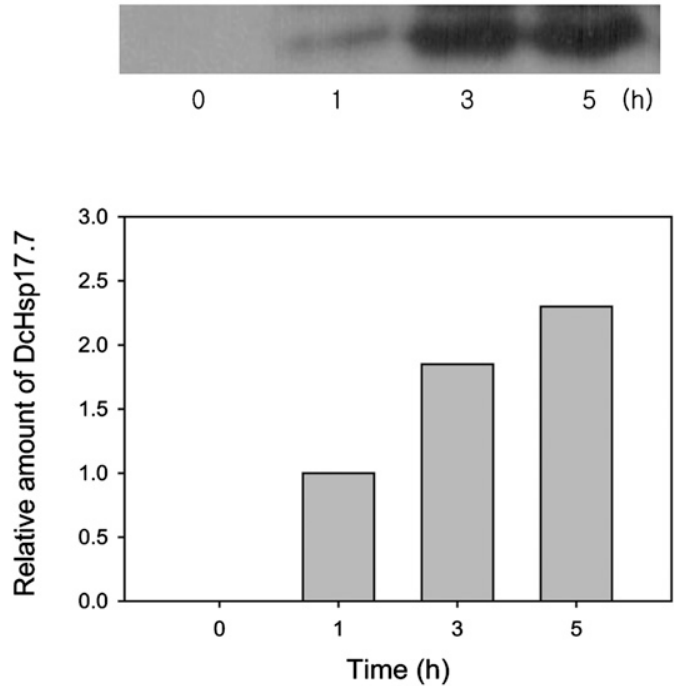

B
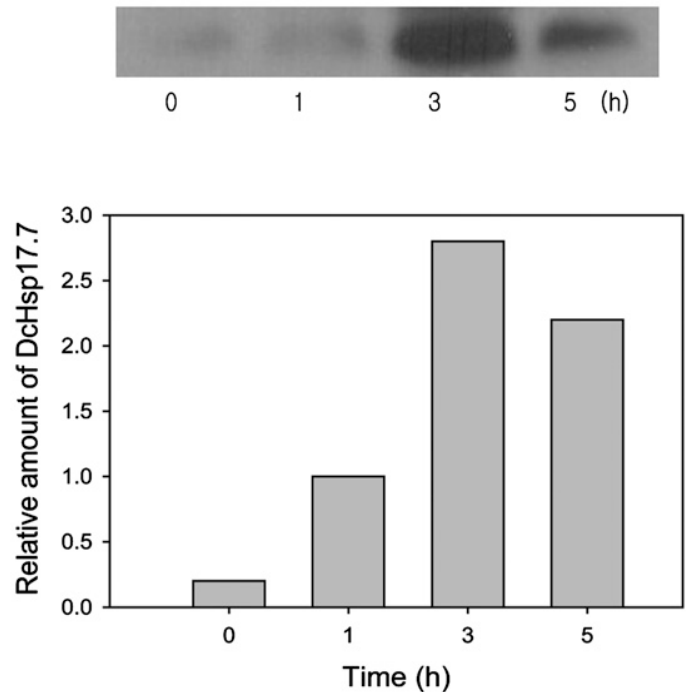

Fig. 3. The accumulation of DcHsp17.7 under oxidative and osmotic stress conditions. Carrot leaf tissues were placed in distilled $\mathrm{H}_{2} \mathrm{O}$ containing either (A) $\mathrm{H}_{2} \mathrm{O}_{2}$ or (B) PEG $(5 \% ; 1,3$, and 5 h). Proteins were extracted under a denaturing condition. Equal amounts of protein $(30 \mu \mathrm{g})$ were resolved on a $17 \% \mathrm{SDS}$ PAGE gel. An immunoblot analysis was performed using a polyclonal antibody raised against DcHsp17.7. Chemiluminescent signals were quantified and the values were normalized to the level of DcHsp17.7 at $1 \mathrm{~h}$ of the stress treatments. $\mathrm{H}_{2} \mathrm{O}_{2}=$ hydrogen peroxide; $\mathrm{PEG}=$ polyethylene glycol; SDS PAGE = sodium dodecyl sulfate polyacrylamide electrophoresis.

A
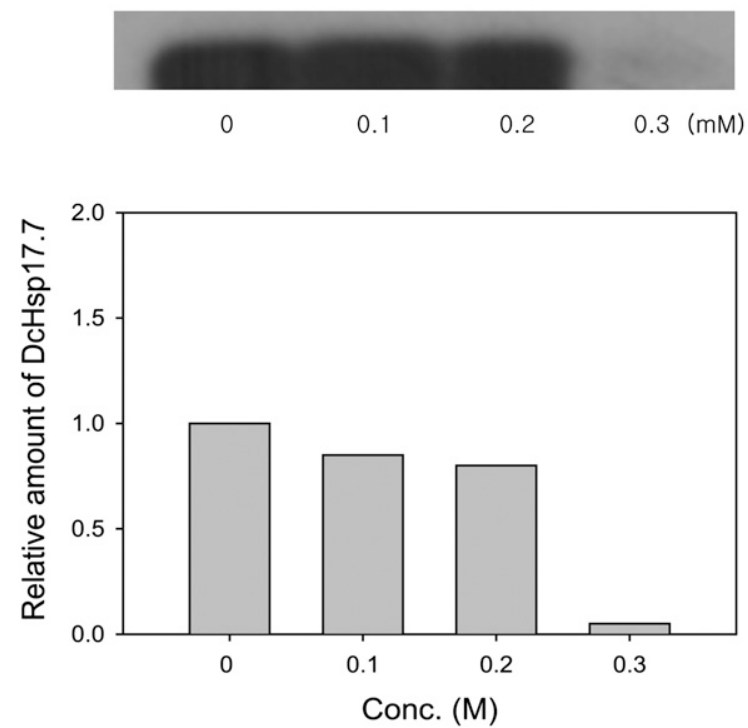
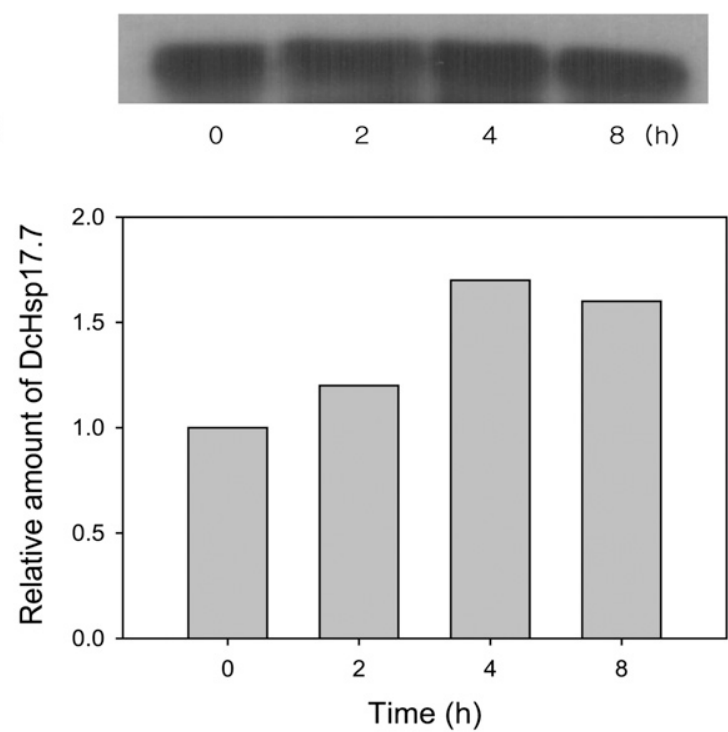

Fig. 4. Heterologous expression of DcHsp17.7 in Escherichia coli. The DcHsp17.7 coding sequence was inserted into a pET11a expression vector and introduced into E. coli. At $2 \mathrm{~h}$ after IPTG treatment, transgenic bacterial cells containing the DcHsp17.7 gene and control cells containing an unmodified expression vector were exposed to $\mathrm{H}_{2} \mathrm{O}_{2}$ (A) up to $0.3 \mathrm{~mm}$ for $3 \mathrm{~h}$ ) and $\mathrm{PEG}(\mathbf{B} ; 20 \%$ up to $8 \mathrm{~h}$ ). Then, proteins were extracted using ultrasonification and resolved on a $17 \%$ SDS PAGE gel. Immunoblot analysis was performed using a polyclonal antibody raised against DcHsp17.7. Chemiluminescent signals were quantified and the values were normalized to the level of DcHsp17.7 before the stress treatments. IPTG = isopropyl b-D-thiogalactopyranoside; $\mathrm{H}_{2} \mathrm{O}_{2}=$ hydrogen peroxide; $\mathrm{PEG}=$ polyethylene glycol; SDS PAGE = sodium dodecyl sulfate polyacrylamide electrophoresis. 
of multiple stress tolerance. Considering the fact that arable lands are subjected to various environmental stresses, understanding multiple stress tolerance in plants is closely related to crop productivity. If proven that sHSPs such as DcHsp17.7 function to confer tolerances to various environmental stresses, they can be used for the development of transgenic plants possessing multiple stress tolerance.

Heterologous expression of DcHsp17.7 in Escherichia coli under oxidative and osmotic stress conditions. To examine its function, the DcHsp17.7 gene was introduced into $E$. coli. IPTG treatment induced the heterologous expression of DcHsp17.7 (Fig. 4). When bacterial cells were exposed to $0.1 \mathrm{~mm}$ and $0.2 \mathrm{~mm} \mathrm{H}_{2} \mathrm{O}_{2}$ for $3 \mathrm{~h}$, the expression level of DcHsp17.7 remained similar to that observed before $\mathrm{H}_{2} \mathrm{O}_{2}$ treatment (Fig. 4A). However, the induction of severe stress from $\mathrm{H}_{2} \mathrm{O}_{2}$ $(0.3 \mathrm{~mm})$ reduced the expression level of DcHsp17.7, although IPTG was present. This may be the result of reduced transcription of the $D c H s p 17.7$ gene and/or degradation of DcHsp17.7 protein under stress conditions. For osmotic stress treatment, the concentration of PEG was increased to $20 \%$, the highest amount that can be used for the experiment, to maximize the stress. PEG treatment did not affect the expression level of DcHsp17.7 in E. coli up to $8 \mathrm{~h}$ (Fig. 4B). Unlike with $\mathrm{H}_{2} \mathrm{O}_{2}$ treatment, we did not observe a decrease in the expression level of DcHsp17.7 in the PEGstressed tissues. In previous studies, the level of heterologously expressed DcHsp17.7 in transgenic E. coli was increased under a heat stress condition (Kim and Ahn, 2009). However, the level was decreased under cold (Song and Ahn, 2010) and salinity (Song and Ahn, 2011) conditions. These results suggest that the heterologous expression of DcHsp17.7 in E. coli driven by IPTG treatment is affected by the type of abiotic stress.

Enhanced cell viability by DcHsp17.7 during oxidative and osmotic stress conditions. To examine whether DcHsp17.7 can confer tolerance to oxidative and osmotic stresses, transgenic E. coli expressing DcHsp17.7 and control cells was exposed to these stress conditions, and cell viability was then examined. As shown in Figure 5, $\mathrm{H}_{2} \mathrm{O}_{2}$ and PEG treatments led to reduced cell viability. However, transgenic E. coli expressing DcHsp17.7 showed a higher level of survival under both stress conditions when compared with control cells containing an unmodified expression vector. Previously, transgenic E. coli expressing DcHsp 17.7 has also shown enhanced cell viability under heat (Kim and Ahn, 2009), cold (Song and Ahn, 2010), and salinity (Song and Ahn, 2011) stress conditions. Our results suggest that DcHsp17.7 could be used to develop transgenic plants possessing multiple stress tolerance.

The molecular chaperone function of DcHsp17.7 under oxidative and osmotic stress conditions. Molecular chaperones enhance protein solubility under stress
A

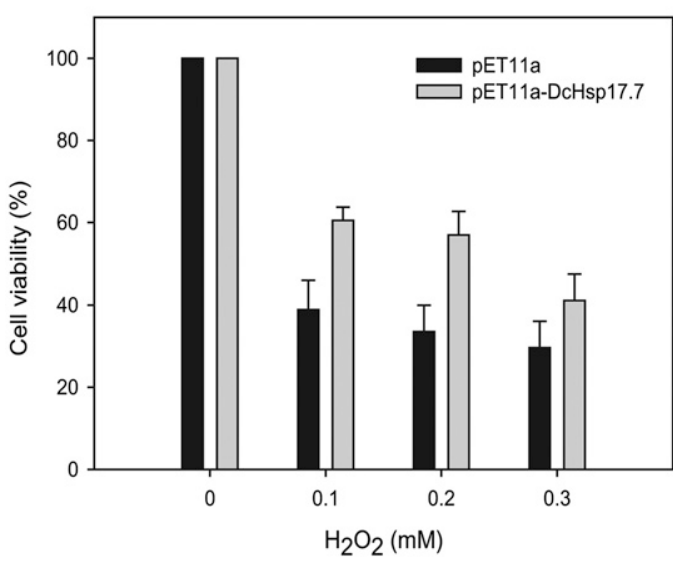

$B$

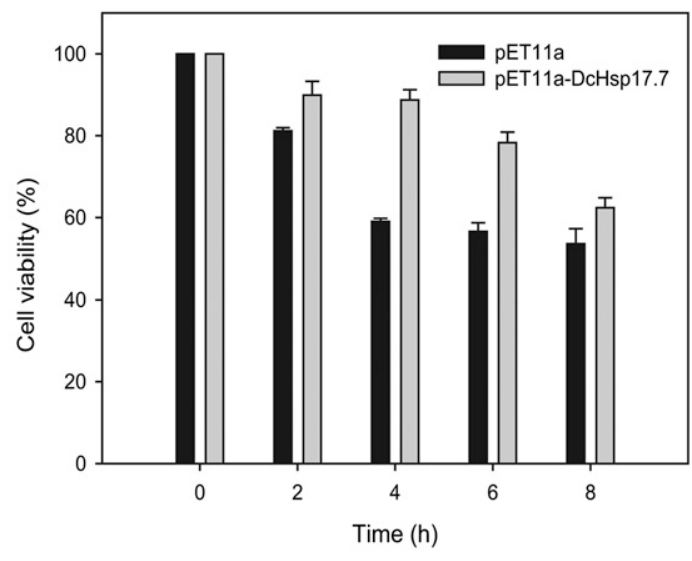

Fig. 5. Enhanced bacterial cell viability by DcHsp17.7 under oxidative and osmotic stress conditions. The DcHsp17.7 coding sequence was inserted into a pET11a expression vector and introduced into Escherichia coli. At $2 \mathrm{~h}$ after IPTG treatment, transgenic and control cells were treated with $\mathrm{H}_{2} \mathrm{O}_{2}$ (A; up to 0.3 mM for $3 \mathrm{~h}$ ) and PEG (B; $20 \%$ up to $8 \mathrm{~h}$ ). Bacterial cells were then plated on LB medium containing ampicillin and incubated at $37{ }^{\circ} \mathrm{C}$. After overnight incubation, the number of surviving colonies was counted and the percentages of survival were calculated. IPTG $=$ isopropyl b-D-thiogalactopyranoside; $\mathrm{H}_{2} \mathrm{O}_{2}=$ hydrogen peroxide; PEG = polyethylene glycol; LB = Luria-Bertani broth.

A

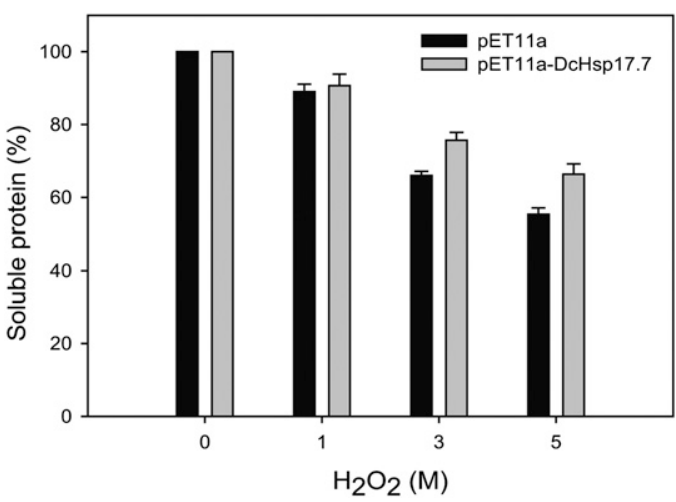

B

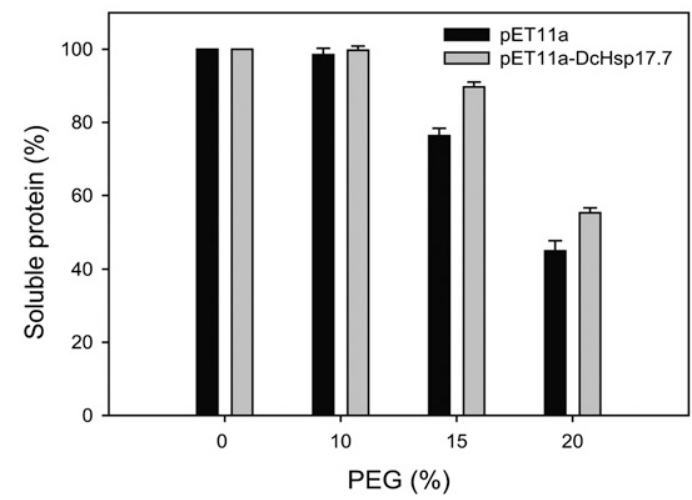

Fig. 6. The molecular chaperone function of DcHsp17.7 under oxidative and osmotic stress conditions. At $2 \mathrm{~h}$ after IPTG treatment, proteins were extracted from transgenic Escherichia coli expressing DcHsp17.7 and control cells. Equal amounts of protein $(900 \mu \mathrm{g})$ were added to $500 \mu \mathrm{L}$ of protein extraction buffer containing either $\mathrm{H}_{2} \mathrm{O}_{2}(\mathbf{A}$; up to $5 \mathrm{M})$ or PEG (B; up to $\left.20 \%\right)$ and incubated at $25^{\circ} \mathrm{C}$ for $2 \mathrm{~h}$. After centrifugation, the amount of soluble protein was quantified by measuring O.D.600. IPTG = isopropyl b-D-thiogalactopyranoside; $\mathrm{H}_{2} \mathrm{O}_{2}=$ hydrogen peroxide; $\mathrm{PEG}=$ polyethylene glycol. 
conditions, resulting in enhancement of cell viability. To examine whether DcHsp17.7 functions as a molecular chaperone under oxidative and osmotic stress conditions, protein solubility was assessed in the absence and presence of DcHsp17.7 expression after $\mathrm{H}_{2} \mathrm{O}_{2}$ (up to $5 \mathrm{M}$ for $2 \mathrm{~h}$ ) or PEG (up to $20 \%$ for $2 \mathrm{~h}$ ) treatments. As shown in Figure 6, these stresses led to decreased expression of soluble proteins in E. coli. However, the expression levels of soluble proteins were consistently higher in the transgenic cells expressing DcHsp17.7 than in control cells under oxidative and osmotic stress conditions. The degree of increase in soluble proteins in transgenic cells expressing DcHsp17.7, when compared with the control, was $10 \%$ at the maximum stress condition, which is similar to that observed during salt-induced stress (Song and Ahn, 2011; less than 15\%). However, under heat and cold stress conditions, the levels of protein solubility in transgenic cells expressing DcHsp 17.7 were increased by $50 \%$ and $30 \%$, respectively (Kim and Ahn, 2009; Song and Ahn, 2010) compared with control cells. These results suggest that DcHsp17.7 functions as a molecular chaperone more effectively under thermal stresses than during other abiotic stress conditions. Additional studies are necessary to examine the molecular chaperone mechanism of DcHsp 17.7 under various abiotic stress conditions.

Genetic engineering appears to be an effective approach to develop crop plants possessing enhanced stress tolerance (BhatnagarMathur et al., 2008). The results in our previous and present studies suggest that DcHsp17.7 appears to be a promising candidate to be used in the transgenic studies for multiple stress tolerance: Transgenic carrot cells and plants overexpressing DcHsp17.7 showed higher thermotolerance under heat stress compared with a control (Malik et al., 1999). When DcHsp17.7 was introduced into potato, a cool-season crop, transgenic potato plants showed enhanced cellular membrane stability and tuberization in vitro under heat stress (Ahn and Zimmerman, 2006). More recent studies showed that, in transgenic $E$. coli, heterologously expressed DcHsp17.7 enhanced bacterial cell viability under various abiotic stress conditions such as heat (Kim and Ahn, 2009), cold (Song and Ahn, 2010), salinity (Song and Ahn, 2011), oxidation and osmotic stresses (present study), and heavy metals (unpublished data) functioning as a molecular chaperone. Further studies are required to generate transgenic plants overexpressing DcHsp17.7 and to examine if the overexpression of DcHsp17.7 can confer tolerance to multiple stresses in transgenic plants.

\section{Literature Cited}

Ahn, Y.-J., K. Claussen, and J.L. Zimmerman. 2004. Genotypic differences in the heat-shock response and thermotolerance in four potato cultivars. Plant Sci. 166:901-911.

Ahn, Y.-J. and J.L. Zimmerman. 2006. Introduction of the carrot HSP17.7 into potato (Solanum tuberosum L.) enhances cellular membrane stability and tuberization in vitro. Plant Cell Environ. 29:95-104.

Ahn, Y.-J. and J.L. Zimmerman. 2007. Cytoplasmic and nuclear localization of DcHsp17.7, a small heat shock protein. Hort. Environ. Biotechnol. 48:207-255.

Ashraf, M. 1994. Breeding for salinity tolerance in plants. Crit. Rev. Plant Sci. 13:17-42.

Basha, E., K.L. Friedrich, and E. Vierling. 2006. The N-terminal arm of small heat shock protein is important for both chaperone activity and substrate specificity. J. Biol. Chem. 281: 39943-39952.

Bhatnagar-Mathur, P., V. Vadez, and K.K. Sharma 2008. Transgenic approaches for abiotic stress tolerance in plants: Retrospect and prospects. Plant Cell Rpt. 27:411-424.

Bradford, M.M. 1976. A rapid and sensitive method for the quantitation of microgram quantities of protein utilizing the principle of protein-dye binding. Anal. Biochem. 72:248-254.

Desikan, R., S.A.H. Mackerness, J.T. Hancock, and S.J. Neill. 2001. Regulation of the Arabidopsis transcriptome by oxidative stress. Plant Physiol. 127:159-172.

Haslbeck, M., T. Franzmann, D. Weinfurtner, and J. Buchner. 2005. Some like it hot: The structure and function of small heat-shock proteins. Nat. Struct. Mol. Biol. 12:842-846.

Haslbeck, M., A. Ignatiou, H. Saibil, S. Helmich, E. Frenzl, T. Stromer, and J. Buchner. 2004. A domain in the N-terminal part of Hsp26 is essential for chaperone function and oligomerization. J. Mol. Biol. 343:445-455.

Higgins, D.G. and P.M. Sharp. 1988. CLUSTAL: A package for performing multiple sequence alignment on a microcomputer. Gene 73:237-244.

Jiang, C., J. Xu, H. Zhang, X. Zhang, J. Shi, M. Li, and F. Ming. 2009. A cytosolic class I small heat shock protein, RcHSP17.8, of Rosa chinensis confers resistance to a variety of stresses to Escherichia coli, yeast and Arabidopsis thaliana. Plant Cell Environ. 32:1046-1059.

Jofré, A., M. Molinas, and M. Pla. 2003. A 10-kDa class-CI sHsps protects $E$. coli from oxidative and high-temperature stress. Planta 217:813-819.

Johnson, P.M., K. Mayrand, and M. Paquin. 2006. The united nations convention to combat desertification in global sustainable development governance, p. 1-9. In: Johnson, P.M., K. Mayrand, and M. Paquin (eds.). Governing global desertification. Ashgate Publishing Limited, Hampshire, UK.

Kim, H. and Y.-J. Ahn. 2009. Expression of a gene encoding the carrot HSP17.7 in Escherichia coli enhances cell viability and protein solubility under heat stress. HortScience 44:866-869.

Lee, B.-H., S.-H. Won, H.-S. Lee, M. Miyao, W.-I. Chung, I.-J. Kim, and J. Jo. 2000. Expression of the chloroplast-localized small heat shock protein by oxidative stress in rice. Gene 245:283-290.
Lindquist, S. and E.A. Craig. 1988. The heat-shock proteins. Annu. Rev. Genet. 22:631-677.

Malik, M.K., J.P. Slovin, C.-H. Hwang, and J.L. Zimmerman. 1999. Modified expression of a carrot small heat shock protein gene, Hsp17.7, results in increased or decreased thermotolerance. Plant J. 20:89-100.

Maqbool, A., W. Abbas, A.Q. Rao, M. Irfan, M. Zahur, A. Bakhsh, S. Riazuddin, and T. Husnain. 2010. Gossypium arboreum GHSP26 enhances drought tolerance in Gossypium hirsutum. Biotechnol. Prog. 26:21-25.

Neta-Sharir, I., T. Isaacson, S. Lurie, and D. Weiss. 2005. Dual role for tomato heat shock protein 21: Protecting photosystem II from oxidative stress and promoting color changes during fruit maturation. Plant Cell 17:1829-1838.

Saitou, N. and M. Nei. 1987. The neighbor-joining method: A new method for reconstructing phylogenetic trees. Mol. Biol. Evol. 4:406425 .

Sarkar, N.K., Y.-K. Kim, and A. Grover. 2009. Rice sHSP genes: Genomic organization and expression profiling under stress and development. BMC Genomics 10:393.

Siddique, M., S. Gernhard, P. von Koskull-Döring, E. Vierling, and K.D. Scharf. 2008. The plant sHSP superfamily: Five new members in Arabidopsis thaliana with unexpected properties. Cell Stress Chaperones 13:183-197.

Song, N.-H. and Y.-J. Ahn. 2010. DcHsp17.7, a small heat shock protein from carrot, is uregulated under cold stress and enhances cold tolerance by functioning as a molecular chaperone. HortScience 45:1-6.

Song, N.-H. and Y.-J. Ahn. 2011. DcHsp17.7, a small heat shock protein in carrot, is tissuespecifically expressed under salt stress and confers tolerance to salinity. New Biotechnol. 28:698-704.

Sun, W., C. Bernard, B. van de Cotte, M. Van Montagu, and N. Verbruggen. 2001. At-HSP17.6A, encoding a small heat-shock protein in Arabidopsis, can enhance osmotolerance upon overexpression. Plant J. 27:407-415.

Sun, W., M. van Montagu, and N. Verbruggen. 2002. Small heat shock proteins and stress tolerance in plants. Biochim. Biophys. Acta 1577:1-9.

Tamura, K., J. Dudley, M. Nei, and S. Kumar. 2007. MEGA4: Molecular Evolutionary Genetics Analysis (MEGA) software version 4.0. Mol. Biol. Evol. 24:1596-1599.

Van Montfort, R., E. Basha, K.L. Friedrich, C. Slingsby, and E. Vierling. 2001. Crystal structure and assembly of a eukaryotic small heat shock protein. Nat. Struct. Biol. 8:10251030 .

Vandenbroucke, K., S. Robbens, K. Vandepoele, D. Inze, Y. Van de Peer, and F. Van Breusegem. 2008. Hydrogen peroxide-induced gene expression across kingdoms: A comparative analysis. Mol. Biol. Evol. 25:507-516.

Vierling, E. 1991. The roles of heat shock proteins in plants. Annu. Rev. Plant Physiol. Plant Mol. Biol. 42:579-620.

Waters, E., G.J. Lee, and E. Vierling. 1996. Evolution, structure and function of the small heat shock proteins in plants. J. Expt. Bot. 47:325-338. 